\title{
AN ATTEMPT AT DELINEATION OF THE EASTERN MISSIONARY ROUTE OF THE CLERGY OF PASSAU ON THE LANDS OF THE POST-AVAR DANUBE REGION DURING THE FIRST HALF OF THE 9TH CENTURY
}

\author{
Ostap Kardash
}

DOI: $10.17846 /$ CL.2020.13.2.3-21

\begin{abstract}
KARDASH, Ostap. An Attempt at Delineation of the Eastern Missionary Route of the Clergy of Passau on the Lands of the Post-Avar Danube Region During the First Half of the 9th Century. The article is devoted to the problem of reconstruction of the possible eastern missionary routes of the clergy of the Diocese of Passau in the Danube region in the first half of the 9th century. By the analysis of the Carolingian diplomas of the 820s and 830s, some diplomas of the last quarter of the 10th century, as well as a significant amount of archaeological data, the eastern vector of missionary activity of monks from the Diocese of St. Stephen is outlined on the lands in Marcha orientalis, mentioned in the diplomas of Louis I the Pious (823) and the Bavarian King Louis II (833 and 836), and which were situated mainly along the both banks of the Danube and its tributaries. The author concludes that these possessions represented a holistic "ecclesial bond", a missionary route that passed through the main monasteries, which were under the church jurisdiction of Passau, as well as through the ancient Roman ways and trade routes that were located in the above-mentioned possessions. In the 830s, after joining of new landholdings around the River Leitha and the Vienna Woods to the Passau's sphere of influence the outlined missionary route reached even the boundaries of the Moravians' settlement.
\end{abstract}

Keywords: The Diocese of Passau, Moravia, missionary route, ecclesiastical jurisdiction, diploma, diploma falsification

The elimination of political independence of the Avar Khaganate in about 796 by the forces of the Frankish King Charlemagne (Karolus Magnus, 742 - 814) and his son, "the King of Italy" ("rex Italiae"), Pippin (Pippinus, 777 - 810) created the favorable conditions for the systematic spreading of Christianity in the eastern borders of the possessions of the Carolingian dynasty (Lechner 1969, 41-42; Ruttkay 2007, 41; Štih 2010, 210-211; Čáky 2016, 21-22), in Moravia and later - in its Danubian provinces (Hudeček 1936, 15; Ratkoš 1971, 73; Floria 1988, 123; Ivanič 2007, 48; Ivanič 2011, 125; Bodnariuk 2012, 808). The most important threat in the face of the Avars disappeared on the way of Christian missionaries. ${ }^{1}$ Since then, the ruling court began to provide the clergy, which carried out the Christianization of the local population of the conquered

1 The remnants of the surviving Avars were allowed to settle between the Danube and the Raba rivers (Lechner 1969, 41; Vlasto 2004, 36), i. e., "between Savaria [the ancient city of Szombathely in Western Hungary - O. K.] and Carnontum [the present-day city of Hainburg on the Danube in Lower Austria O. K.]" ("inter Sabariam et Carnontum") (Annales regni Frankorum 1895, 119; Annales Tiliani 1966, 58; Szőke 2002, 249; Štefanovičová 1989, 69; Třeštík 2009, 93) under the rule of Khagan Theodore (Theodorus, $\dagger$ after 805 ), who was baptized and accepted his Christian name right after the military defeat by Charlemagne (Annales regni Frankorum 1895, 120; Annales Tiliani 1966, 59; Lechner 1969, 41; Vlasto 
territories, with a regular force support, because in the same way the Carolingians regularly sent their troops, in particular, "to the land of the Slavs, called Bohemians" (Annales regni Frankorum $1895,120)^{2}$ and "in Pannonia to complete the controversies between the Huns [the Avars - O. K.] and the Slavs [probably, even the Moravians - O. K.] [...]" (CDEM I 1836, 7). ${ }^{3}$

In order to discuss the missionary tasks and methods of evangelization of the population, previously controlled by the Avars, a congress with the participation of the Patriarch of Aquileia Paulinus II (Paulinus, 730/740 - 802) and the Bishop of Salzburg Arno (Arn/Arnonus, 784 - 821) took place in the military camp of Pippin (Ivanič 2007, 47; Ivanič 2011, 124; Nótári 2007, 98; Ćáky 2016, 20-21; Ruttkay 2016, 4). The Slavic lands south of the middle Danube, controlled previously by the Khaganate, became a part of the Carolingian possessions. By the decision of Charlemagne, the territory north of the Drava (a southern tributary of the Danube) was generally recognized as the sphere of missionary activity of the Bavarian Church (Kučera 1985, 7; Floria 1988, 123; Kožiak 2006, 141). The Diocese of Salzburg became a main Christianization medium and a center for the already baptized local population (Ratkoš 1971, 75; Bekker 2012, 930), and on April 20, 798 was transformed into the archbishopric (CDEM I 1836, 3-4; Kožiak 2006, 140; Nótári 2007, 100).

Similarly to Ludevít Knappek $(1935,240)^{4}$, the Slovak archaeologist and historian Alexander Ruttkay $(2007,41)$ states, that initially the Slavic lands, the former Avarian possessions, were distributed by the following way: the territories between the Raba, the Drava and the Danube became a missionary zone of the Archbishopric of Salzburg, the lands west of the Raba turned to the sphere of influence of the Passau episcopate, the possessions within the principality of Nitrava passed under the ecclesiastical jurisdiction of the Bishopric of Regensburg and, finally, the southern margins between the Drava and the Sava rivers (a right tributary of the Danube) answered to the Patriarchate of Aquileia. This conception of delimitation of the above-mentioned dioceses' missionary areas is supported by another Slovak historian, Andrej Botek $(2014,24)$. However, we must admit that this eparchial division wasn't always consistently respected, because of a number of factors (Ruttkay 2007, 41-42) connected, primarily, with the conflicts around the missionary areas of the listed dioceses of the Bavarian Church and their demarcation during the first half of the 9th century (CDEM I 1836, 9-10, 18; MMFH III 1969, 19-23).

Having eliminated the Avarian threat and organizing a regular military support in the postAvar area, particularly in the Eastern March (Marcha orientalis) (Bowlus 1995, 3), Carantania and, in fact, in the Moravian lands (CDEM I 1836, 7-8), the ruling Carolingian court and the local elites began to assist the clergy of provincial monasteries also materially for the purpose of consistent institutionalization of the Latin Church in the outlined region. Besides, in this period the Carolingians spread their influence on the east often through the connections with local monastic centers (Good 2012, 205), granting them generous donations (Good 2012, 187). Therefore, other monasteries, founded by the Bavarian duke Odilo (Ottilo, $700-748$ ) and his

2004, 36; Szőke 2002, 249). Afterward his successors were also baptized (Ratkoš 1971, 76; Vlasto 2004, 36).

2 "[...] in terram Sclavorum, qui vocantur Beheimi" (Annales regni Frankorum 1895, 120).

3 "[...] in Pannonia ad controversias Hunorum et Sclavorum finiendas [...]" (CDEM I 1836, 7). For instance, two of such military campaigns took place in 811 on the initiative of Charlemagne, in order to secure a peace between the Slavs and the Avars"around the Danube" ("circa Dunabium") (CDEM I 1836, 7-8; Štih 2010, 130; Ćáky 2016, 23). Once again it proves that the conquest and mastering of new lands were accompanied by the missionary activity and Church institutionalization (Lechner 1969, 42).

4 In the 1930s the Slovak historian Ludevít Knappek $(1935,240)$ argued that at the turn of the 8th - 9th centuries the area between the rivers of Drava, Raba and Danube, as well as the northern part of Lower Pannonia, belonged to the missionary zone of Salzburg, the lands north-west of the Raba to the Diocese of Passau, and the region south of the Drava to the Patriarchate of Aquileia. 
son Tassilo III (Tassilo, 741 - 796) continued to play not less important role in the process of Christianization of the local population and the Church institutionalization in the specified areas (Vlasto 2004, 33; Good 2012, 196-218). In particular, there were the Benedictine monastery (since 804) of Mondsee (Ratkoš 1971, 75; Ivanič 2007, 48; Ivanič 2011, 125; Good 2012, 197, 199), the monastic centers in Chammünster (Parello 2015, 103; Good 2012, 200), Innichen (Vlasto 2004, 33; Good 2012, 202-203), Niederalteich (Ratkoš 1971, 75; Ivanič 2007, 48; Ivanič 2011, 125) and, especially, the Monastery of Kremsmünster (Ratkoš 1971, 75; Klíma 2001, 14; Vlasto 2004, 33), in organization of which the bishops from Salzburg, Passau and Regensburg were actively involved (Vlasto 1970, 16; Vlasto 2004, 33).

Generally, at the beginning of the 9th century the missionary potential of the Bavarian clergy became prominent enough, so the conflicts over the precession in evangelistic work in the outlined area began to emerge between the dioceses of the Bavarian Church. While the missionaries of Salzburg acted mainly in Carantania and Lower Pannonia (Hudeček 1936, 16; Lechner 1969, 42; Wolfram 1972, 15; Wolfram 2011, 66-67; Štih 2010, 211; Steinhübel 2016, 86-87), the preachers from the Diocese of Passau launched their evangelistic activity in the area populated by the Slavs, west of the Raba River (Ruttkay 2007, 41) and, in particular, in the valley of the Morava River (Hudeček 1936, 16; Floria 1988, 124; Vlasto 2004, 39; Rops 2014, 437). On this backdrop, in the 820s the contradictions emerged between the Bishopric of Passau and the Archbishopric of Salzburg over the lands of the Eastern March and the area east of the Vienna Woods ("ultra Comagenos montes”) (CDEM I 1836, 18; MMFH III 1969, 120; Lechner 1969, 42, 53; Konečný 1975-1976, 9; Floria 1988, 123-124; Steinhübel 2016, 124-125), through which all the "missionary routes" of the mentioned dioceses' clergy passed. In 791 the boundary of Charlemagne's state was shifted from the river of Enns to the river of Raba (Richter 1965, 130; Steinhübel 1995, 10; Vlasto 2004, 39), where the newly captured territories between the Inn (a right tributary of the Danube) and the Raba rivers, as well as between the Raba and the Vienna Woods (Upper Pannonia) were subjected to the jurisdiction of the Diocese of Passau (Richter 1965, 130; Steinhübel 1995, 15; Steinhübel 2016, 124; Nótári 2007, 99). Accordingly, the ecclesiastical jurisdiction of Salzburg extended in the lands south and east of the Raba (Richter 1965, 130; Lechner 1969, 42; Ruttkay 2007, 41).

From then, the missionary and church-institutionalization practice of the Passau clergy in the above-mentioned area received support from the Carolingians, in the person of the repeatedly mentioned Emperor Charlemagne and his son Louis I the Pious (Ludovicus/Hluduuucus Pius, $778-840$ ). The last one, for example, by his diploma, proclaimed during the imperial congress in Frankfurt, at the request of the Bishop of Passau Reginhar, (Reginarius/Ragenarius, 818 - 838) confirmed the father's donation to the Passau episcopate of "certain places" ("quaedam loca") in the Eastern March, including "Treismam, Wachowam, Pelagum, Nardinum, Reoda, Aspach, Wolffeswanch, Erlawam et in Artagrum basilicas duas [two basilicas - O. K.] et in Saxinum basilicas duas [two basilicas - O. K.]" (MMFH III 1969, 21-22). ${ }^{5}$ Previously, these possessions were seized

In the modern geographic dimension the above-mentioned places should be understood as follows: Treisma - the archaic nomination of the modern-day city of St. Pölten, the capital of the federal land of Lower Austria (Klebel 1955, 321, 324; Erkens 1986, 87; Pleser 1998, 456; Weber 1999, 77), which was firstly mentioned in 799, when the possession of Treisma was granted by Charlemagne to the Diocese of Passau (Klebel 1955, 321; Erkens 1986, 108; Pleser 1998, 456). The city was named after the Monastery of St. Hippolyte, which was founded near the Benedictine Abbey of Tegernsee by the beginning of the 9th century - most probably around 799 (Plesser 1998, 456; Weinzierl 2018, 20, 22).

Wachowa - the Wachau, a valley of the Danube in modern-day Lower Austria, between the cities of Melk and Krems (Reutter 1912, 36; Klebel 1955, 319, 324; Mauer 1985, 74; Erkens 1986, 87). Probably, the possessions of the Passau episcopate in the valley of Wachau, according to the diploma of Louis I (823), 
illegally from the ecclesiastical jurisdiction of the Diocese of Passau by the Prefect of the Eastern March, Count Gotafrid (Godofredus/Gotafredus, бл. 806 - 811/not later than 826), therefore, Bishop Reginhar needed the patronage and appropriate sanction of Louis I (CDEM I 1836, 13; MMFH III 1969, 22; Erkens 1986, 86; Weber 1999, 77).

Besides the aforelisted possessions, in the extended and farther version of the imperial diploma of 823, which is stylistically somewhat different, but still doesn't lose the content of the previous text (Erkens 1986, 87), "a certain place, called Litaha, and Zeizzinmurum in the lands of the Huns" (CDEM I 1836, 13; MMFH III 1969, 118) were also guaranteed to the Passau episcopate. ${ }^{6}$ Long time ago, historians proved that the aforementioned version of the document

included present-day Wesendorf and St. Michael with St. Michael's Monastery (Winter 1998, 431; Weber 1999,78 ), which was founded by Charlemagne at the beginning of the 9th century on the site of pagan [probably, Celtic - O. K.] altar (Mauer 1985, 76-77).

Pelagum - the Pielach River, a southern tributary of the Danube, which flows into it in the city of Melk, south of the Wachau (Klebel 1954, 89; Klebel 1955, 324; Erkens 1986, 87; Weber 1999, 77-78). In the diploma of Louis I (823) the mentioned nomination should be understood, evidently, also as a certain delineation of lands around the river of Pielach, which were covered by the ecclesiastical jurisdiction of the Bishopric of Passau. It is known that exactly during this period the clergy from Passau asserted the right to own the territory of Schönbühl (the modern-day cognominal municipality in the district of Melk, Lower Austria) at the Pilach River mouth (Klebel 1954, 89).

Nardinum - the ancient Indo-European nomination of the Naarn River, a left northern tributary of the Danube, which flows into it south of the city of Perg, near Linz in Upper Austria (Erkens 1986, 87; Weber 1999, 77; Krawarik 2008, 35; Holub 2014, 116-117). This name also means a certain group of lands around the mentioned river (Müller 1915, 123).

Reoda - the nomination, identical, apparently, to the present-day municipality of Ried in der Riedmark (the district of Perg) in Upper Austria (Müller 1915, 123; Klebel 1955, 324; Erkens 1986, 87; Krawarik 2014, 54). However, the modern German historian Andreas Otto Weber $(1999,77)$ considers, that it is the present-day municipality of Ried im Traunkreis (the district of Kirchdorf an der Krems) in Upper Austria.

Aspach - the modern-day municipality of Ashbach (the district of Amstetten) in Lower Austria (Reutter 1912, 36; Müller 1915, 123; Klebel 1955, 325; Erkens 1986, 87; Weber 1999, 78).

Erlawa - the Erlauf River, a right tributary of the Danube near the city of Pöchlarn (the district of Melk) in Lower Austria (Haberl 1976, 153; Erkens 1986, 87; Weber 1999, 78) and, apparently, a certain definition of territories (probably, even of the above-mentioned city) around the river, which, according to the diploma of Louis the Pious, were covered by the ecclesiastical jurisdiction of the Diocese of Passau. However, Johanna Haberl, an Austrian historian $(1976,153)$, associates the nomination Erlawa/Erlafa etymologically only with the Erlauf River, excluding its connection with the city of Pöchlarn.

Wolfeswanch - most probably the archaic nomination of the modern-day municipality of Wolfsbach (the district of Amstetten, Lower Austria) (Klebel 1955, 320; Tisch 2013). However, the exact definition of this oikonim is very controversial (Reutter 1912; Erkens 1986, 87, 108; Weber 1999, 77; Tisch 2013), therefore, this problem requires a special research. According to the assumption of the Austrian-German historian Ernst Klebel $(1955,320,326)$, Wolffeswanch, as well as Erlawa and Aspach among the 12 listed possessions, were the later insertions, evidently, of the end of the 9th century. But in our opinion, there are no compelling reasons for such conclusions.

Artagrum - the present-day municipality of Ardagger (the district of Amstetten) in Lower Austria. Saxinum - the modern-day municipality of Saxen (the district of Perg) in Upper Austria (Reutter 1912, 36; Klebel 1955, 325; Weber 1999, 78; Erkens 1986, 87).

6 "[...] quondam locum, qui vocatur Litaha, et in terra Hunorum Zeizzinmurum [...]" (CDEM I 1836, 13). Litaha - the archaic nomination of the Leitha River, a right tributary of the Danube in Lower Austria and Hungary (Šembera 1858, 30), and at the same time, probably, a certain delineation of lands around it, which became a part of the episcopal possessions of Passau (see the remark: MMFH III 1969, 119).

Zeizzinmurus - the original nomination (among its other variants: Zeizinmura, Zeysenmurus, Cezurum) of the present-day municipality of Zeiselmauer in the district of Tulln (Lower Austria) (see the remark: 
is the late falsification, created between 971 and 977, or in 985, according to another conception, (Klebel 1955, 319, 324; Haberl 1976, 114; Erkens 1986, 89, 91; Weber 1999, 77; Krawarik 2008, 74), because the possessions Litaha and Zeizzinmurus (mentioned in the falsification), as a church beneficium, were granted to the Bishopric of Passau only in 830s and, moreover, by the King of Bavaria (rex Baioariorum, 817 - 843) and the future King of the Eastern Frankish Kingdom Louis II the German (Ludovicus/Hludowicus, 843 - 876) (MMFH III 1969, 32-35; Erkens 1986, 87, 92-93). ${ }^{7}$ However, the list of lands, intended to the Diocese of Passau in the imperial diploma of Louis I, is worth considering more carefully and in a slightly different light.

In our opinion, the identification of modern names of the territories, mentioned in this document, and their location on the map in the present-day geographic space allows us to interpret the appropriate fragment of the confirmation of Louis the Pious from 823 not just as a list of possessions, granted to the Diocese of St. Stephen by the emperor. Situated along the entire course of the Danube, both on the left (north) and on the right (southern) shore (Klebel 1955, 324-325), these possessions represented a peculiar "ecclesial chain" and the outlined missionary

MMFH III 1969, 119; Müller 1915, 125; Haberl 1976, 56; Erkens 1986, 87). There, on the site of ancient Roman fortifications, which were a part of the Danube Limes fortifications, and on the site of the legionary camp Cannabiaca in the 5th century, one of the oldest hall church of Lower Austria (Saalkirche) was constructed (Gessner - Pülz 2015, 11; Schwacz 2016, 80). It existed during the 9th century (Geschichtliche Beilagen 1890, 198) and the parts of its lower walls and crypts are still in use in the Church of the Immaculate Conception of St. Maria in Zeiselmauer (Genser 1982, 65; Gessner - Pülz 2015, 19). During the period of ecclesiastical-legal submission of Zeiselmauer to the Episcopacy of Passau, the complete settlement has already existed there, which is confirmed archaeologically (Weinzierl 2018, 22).

In this case, some Latin nominations of the rest of the previously mentioned possessions are recorded in a different way in the extended version of the diploma: Tresma, Vuachouua, Pelagum, Nardinum, Reode, Asbahe, Vuoluesvuanch, Erlafa, Artagrum, Saxina (CDEM I 1836, 13; MMFH III 1969, 118; Erkens 1986, 91-92).

7 The extended version of Emperor Louis' diploma is quite rightly considered as the falsification of the Bishop of Passau Pilgrim (Pilegrinus/Peregrinus, 971 - 991) by the absolute majority of researchers (Klebel 1955, 319; Haberl 1976, 114; Erkens 1986, 89, 95; Weber 1999, 77). It is evidenced, firstly, by the conclusions of the paleographic analysis of the text, secondly, by the fact that the lands around the river Litaha were granted to the Passau Diocese of St. Stephen not by Emperor Louis I the Pious, but by his son, Louis II the German a decade later - on March 4, 833 (MMFH III 1969, 32-33; Erkens 1986, 87) and three years later - on February 16, 836 - also the territory of Zeizzinmurus (MMFH III 1969, 34-35; Erkens 1986, 92-93). There is an assumption that this falsification originated with the participation of the Chancellor of Imperium Romanum and the Archbishop of Mainz at the same time - Willigis (Willigisus, around $940-1011$ ) around 985, and, consequently, came from the chancellery of Emperor Otto III (Otto III, 980 - 1002) (Erkens 1986, 89). Perhaps, it was created in 985, on the judgment day, convened by the Bavarian duke Henry II the Wrangler (Heinricus, 951 - 995) in order to establish his own rights to Zeiselmauer (Erkens 1986, 95) during his struggle for the Bavarian Duchy.

However, as we have already found out, by the moment of creation of the falsification, the Diocese of Passau had possessed both the lands around Litaha and the territory under the nomination Zeizzinmurus for almost 150 years. Therefore, Bishop Pilgrim had no reasons to fabricate the evidences of the previous (short) version of the diploma of Louis I since 823 (Erkens 1986, 92), because there were another relevant diplomas since 833 and 836 , related to the providing of the above-mentioned possessions to the clergy of Passau (MMFH III 1969, 31-35). Consequently, the episcopate fully possessed the ecclesial right to the outlined lands, which, according to the German historian Franz-Reiner Erkens (1986, 93), "had to be secured or extended due to the falsification". So, the evidences of both - short and extended versions (taking into account the moment and circumstances of falsification of the last one) confidently can be used for our research purposes (Weber 1999, 77; Krawarik 2014, 54). 
route of the Passau clergy at the same time. ${ }^{8}$ On many lots it coincided with the ancient late Roman roads, which were preserved and, apparently, used during the first half of the 9th century (Reutter 1912, 14, 23-24, 28-29, 32, 36; Maurer 1985, 14; Krawarik 2014, 42) for the missionary purposes. ${ }^{9}$ For instance, at the beginning of the 20th century the Austrian historian Hans Reutter $(1912,36)$ argued that the lands of Wachowa (the Wachau), Nardinum (the Naarn), Artagrum (Ardagger) and Saxinum (Saxen) were located near the ancient Roman road already in the period of Emperor Charlemagne. ${ }^{10}$ For his part, the modern Austrian historian Hans Krawarik (2008, 42) emphasizes the existence of the "very ancient" [apparently, ancient Roman - O. K.] path of Naarn - Baumgarten - Loa - Hörstorf, east of the above-mentioned territories. ${ }^{11}$

As we have mentioned, the Carolingians spread their influence on the eastern, transboundary lands due to the connections with the local monasteries (Good 2012, 205), which at that time were not only the means of colonization and Church institutionalization on new territories (Good 2012, 196, 199), but also served as the supporting points of communication routes and military expeditions (Good 2012, 196, 219). Consequently, this route, most obviously, passed also along the line of most important monasteries, which were located in the aforementioned lands and recognized the ecclesiastical jurisdiction of the Bishopric of Passau. In particular, there were, the Monastery of St. Hippolyte in Treisma (MMFH III 1969, 21; Erkens 1986, 105; Plesser 1998, 456;

8 E. Klebel (1955, 324-325), conversely, denied any logical connection between the above-listed land grants, given that the order of their placement from the east to the west in the diploma of Louis I is violated, the sequence is unsystematic, and the records of some lands (Wolffeswanch, Erlawa й Aspach), according to the historian, were not original, but later insertions (Klebel 1955, 320, 326). However, we consider that it was determined, more plausibly, by the often fuzzy fixation of territorial estates, typical for many early medieval diplomas. Consequently, there are no reasons to doubt that the Passau possessions belonged to the determined missionary direction.

9 A qualitative ancient Roman network of roads, laid by the huge stone-hewn blocks and constantly repaired almost to the beginning of the 5th century, had been in use for the next four centuries without special care, and formed the basis of the Frankish road network (Reutter 1912, 23), linking up the settlements of the Franks, especially the listed possessions of the Passau episcopate (Reutter 1912, 24, 28-29, 36). In our opinion, once again it proves the existence of the determined missionary route of the Passau (and not only Passau) clergy in the above-outlined paths of the former Danube Limes in the period of Louis I the Pious and Louis II the German.

10 In general, the researcher admitted that all the royal lands and farms of the Carolingians were located along the ancient Roman roads from Passau through Lorch to Vienna, and from there through Savaria to the Pannonian city of Sirmium [the modern-day city of Sremska Mitrovica in Serbian Vojvodina, on the left bank of the Sava River - O. K.], or through the ancient city of Flavium Solvense [in the former Roman province of Norik, nearby the present-day Austrian cities of Wagna and Leibnitz in Styria - O. K.] to Virunum [the former Roman city in the province of Norik, in the valley of Zollfeld, in the modern-day South-Austrian province of Carinthia - O. K.], as well as along the Danube, from Passau through Lorch to Carnunt [Carnuntum - a former ancient Roman legionnarie camp, later - the Pannonian city in the present-day municipality of Petronell-Carnuntun in Lower Austria - O. K.] (Reutter 1912, 32). These roads, according to archaeological explorations by J. Haberl (see the detailed delineation of mentioned roads: Haberl 1976, 108-109), also reached the Italian city of Aquileia and, in particular Emona (Aemona) [the modern-day city of Ljubljana, Slovenia - O. K.], a former ancient Roman military camp (Haberl $1976,108)$. Consequently, the above-mentioned possessions, granted to the Diocese of Passau in 823 836, territorially were completely fitted to the outlined routes (Reutter 1912, 24, 33-34, 36).

11 Later, these and other lands located between the Aist and Naarn rivers, will become the possessions of the Diocese of Regensburg, according to the diploma of King Louis the German since 853 (MMFH III 1959, 42-43; Krawarik 2008, 42; Krawarik 2014, 92). 
Weinzierl 2018, 22) ${ }^{12}$, the Monastery of St. Michael in the valley of Wachau (Wachowa) (MMFH III 1969, 21; Weber 1999, 78) ${ }^{13}$, obviously, the hall church of the Carolingian period on the site of the present-day Church of St. Vitus within Wolffeswanch ${ }^{14}$ along with the possession of Aspach, (Tisch 2013), the Monastery of St. Remigius in Reoda (Krawarik 2014, 54, 76) ${ }^{15}$, the unknown "two basilicas in Ardagger" ("in Artagrum basilicas duas"), "two basilicas in Saxen" ("et in Saxinum basilicas duas") (CDEM I 1836, 13; MMFH III 1969, 22; Erkens 1986, 87; Weber 1999, 78), one of which is, evidently, the present-day Church of St. Stephen in Saxen (Dessl OCist 2002, 175; Krawarik 2008, 74; Krawarik 2014, 76) ${ }^{16}$, as well as, probably, the Church of St. Michael in the land of Nardinum (Krawarik 2008, 96; Krawarik 2014, 54, 76), granted to the Diocese of Regensburg

12 According to the Austrian historian Herbert Franz Weinzierl $(2018,22)$, the Monastery of St. Hippolyte was "the supporting point of Passau", in which the church synods were held to organize "the events devoted to the Christianization of the eastern [the Moravian and Nitranian - O. K.] lands". Its clergy spread Christianity across the entire region (Havlík 1963, 106; Klíma 2010, 4). This is evidenced, in particular, by the fact that this monastery became "maternal" for the ancient monastery in the city of St. Hippolyte (in the modern-day southern Moravian city of Znojmo, Southern Czech Republic), as well as for the same monastery of St. Hippolyte at the foot of the Mount Zobor (about 880) in the present-day Slovak city of Nitra (Havlík 1956, 10; Havlík 1998, 19; Klíma 2000, 66; Klíma 2001, 48; Klíma 2010, 4; Marsina 1992, 412; Marsina 2012a, 25-26; Ruttkay 2007, 42; Ruttkay 2016, 6; Steinhübel 2016, 215). Their appearance was the result of missionary activity and, thus, the spreading of the cult of St. Hippolyte in Great Moravia and the Principality of Nitra under its rule by the clergy from the Passau Diocese during the 9th century. (Havlík 1956, 10; Ratkoš 1971, 78; Klíma 2000, 66; Klíma 2001a, 13-14; Klíma 2001b, 48; Klíma 2010, 6; Steinhübel 2014, 44, 46). Accordingly, the Slovak historian Richard Marsina (2012a, 22) suggests that missionaries from the aforementioned Monastery of St. Hippolyte (Treisma) could visit Nitrava since the end of the 8th century. The aforementioned author, as well as another Slovak historian Ján Steinhübel $(2016,215)$, refers an occurrence of the eponymous local monastic center at the Mount Zobor to the last quarter of the 9th century, associating it with the activities of the Great Moravian Prince Svatopluk (Zuentibald/Zuendibolch, 840(?) - 894) and the Bishop of Passau Wiching (Wichingus, ? - 899) (Marsina 2012a, 25; Marsina 2012b, 115). Based on the long-term archaeological researches of the remnants of the Christian churches in Znojmo and burials within them (since 1986), the Czech archaeologist Bohuslav Klíma (junior) suggests that the initial phase of constructing of the Moravian monastery in the city of St.Hippolyte is dated exactly from the first third - the middle of the 9th century and is associated with the missionary activity of the Passau episcopate in Moravia. The other phase is dated back to the end of the 9th century (Klíma 2000, 66; Klíma 2001a, 14, 22; Klíma 2001b, 48; Klíma 2010, 6), i. e., to the period of completion of the canonical confrontation between the Bavarian clergy and the representatives of the Cyril and Methodius church tradition. The cult of St. Hippolyte was present among the others exactly in the ecclesiastical tradition of the Diocese of Passau (Ratkoš 1971, 78). This fact confirms again an existence of the mentioned missionary route of the Passau clergy, which passed along the line of the most important monastic centers in the possessions provided by the diploma of Emperor Louis since 823, where the ecclesiastical jurisdiction of the Diocese of Passau spread.

13 In the words of A. O. Weber $(1999,78)$, this monastery "was the main church and baptistery of the Wachau already during the Carolingian period".

14 In the process of archaeological researches, which were carried out as a result of reconstruction of the foundations of the St Vitus Church in the community of Wolfsbach (Lower Austria) in 2011, a small rectangular hall church with a square apse was discovered, which, according to some researchers' assumptions, belongs to the Carolingian epoch and certifies an existence of the organized church parish Wolffeswanch already in the 9th century (Tisch 2013), that is, just in the period of appearance of this toponym in the diploma of Louis I from 823.

15 In addition, it is worth emphasizing that the monastery center in Reode, as H. Krawarik states (2014, 54), was still too small at the time of its first mention (823). Perhaps, during the period of its founding ( $800-820$ s) this monastery was located outside the modern-day Riddorf in Upper Austria (Krawarik 2014, 54).

16 H. Krawarik $(2008,74 ; 2014,54,96)$ seems to be right denying the identification of one of Saxen basilicas 
in 853 (Krawarik 2014, 92). After the accession of Zeizzinmurus to the possessions of the Passau Church on March 16, 836 (MMFH III 1969, 34-35; Erkens 1986, 92-93) the original monastic center [on the site of the modern Church of the Immaculate Conception of St. Maria - O. K.] in Zeiselmauer (Geschichtliche Beilagen 1890, 198; Weinzierl 2018, 22) was added to this list.

The ecclesiastical connection between the listed monasteries and the cities in which they were located, was established using the already mentioned ancient Roman roads (Reutter 1912, 23-36; Maurer 1985, 14; Krawarik 2008, 42), trade routes (Klíma $2010,5)^{17}$, as well as by the rivers of Danube, Pielach, Naarn, Erlauf and Leitha and by the lands around them. The emergence of the Trans-European system of roads from the Iberian Peninsula through Eastern Bavaria and Moravia to the borders of the Khazar Khaganate until the middle of the 9th century could have also contributed to the development of such communication (Leont'ev - Nosov 2012, 386).

The land grant of Louis I to the Church of St. Stephen, and, thus, the outlined missionary route, were located along the Danube, which on many sites served as the peculiar BavarianSlavic (Balcárková - Kalhous - Eichert 2017, 38, 62) and the Frankish-Slavic frontier, the eastern imperial border of the Carolingian State (Reutter 1912, 28; Fedeles - Koszta 2011, 9-10; Dubski 2012, 84-85) ${ }^{18}$, separating it from the Moravians (Reutter 1912, 28; Lampel 1915, 129; Floria 1982,

with the present-day Church of St. Nicholas in Hofkirchen (the district of Perg, Upper Austria), which, according to him, was founded only at the end of the 10th century: in the 970s -980s.

17 For instance, the settlement and ancient church in Znojmo (one of the oldest Great Moravian sacral constructions), which, as we have already mentioned, were derived from the Lower Austrian monastery of St. Hippolyte and where the Passau clergy reached, located on the ancient trade route (of iron and salt) that passed from the Danube to the above-mentioned Znojmo and was the shortest connection of southwestern lands with Moravia. Therefore, it was impossible for the missionaries to miss this settlement, "the first centre in the "buffer zone" with Western neighbours", - according to B. Klíma $(2010,5)$, and, consequently, one of the points of the repeatedly mentioned missionary route of the clergy from Passau on its eastern segment.

18 It is wrong to diminish the value of the mentioned river, as a conditional line of the Frankish-Slavic frontier. But at the same time, it's worth remembering that the eastern borders of the Carolingian possessions (in particular, the Eastern Frankish Kingdom after 843) were quite dynamic during the 9th century, constantly changing under the influence of expansionary policy of the ruling court, Christianization, the constant dilatation of jurisdiction of the Latin Church and Frankish colonization on the lands of smaller, semidependent Slavic state formations (Dubski 2012, 81-92). Such a phenomenon was completely typical for that time, whereas, according to the right statement of the Czech historians Adéla Balcárková and David Kalhous, as well as the Austrian - Stefan Eichert (2017,38), any border in the early Middle Ages "hardly was a two-dimensional linear structure", rather "a contact zone" or "the entire landscape, which stretched along the predicted boundary line". Thus, H. Reutter $(1912,29)$ considered that "the almost impenetrable band" of the Northern Woods, which separated the Carolingian state from the Slavic possessions [in Bohemia and Moravia - O. K.] in the south, was the real imperial border, rather than the Danube, which was called "the secondary reference point" by the author. This assertion is admissible, seeing that the numerous Frankish and Slavic settlements were located on both sides of the Danube River (Reutter 1912, 29; Krawarik 1971, 197; Krawarik 2008, 36, 92-93), and benefaction of Louis the Pious to the Passau episcopate since 823, as well as subsequent donations of Louis II the German to another Bavarian dioceses, actually, meant the expansion of the Carolingian Empire, and subsequently the Eastern Frankish Kingdom further east and north through the expansion of the ecclesiastical jurisdiction of the Latin Church (Dubski 2012, 86-87). In some regions the Carolingian influence conversely didn't even reach the Danube flow. In particular, it is well illustrated by the conclusions of the modern Hungarian historians Tamaš Fedeles and László Koszta (2011, 10), who emphasize that in Pannonia of the specified period the Frankish sovereignty extended only to the Western Danube region - to the western shore of the Lake Balaton, that is evidenced by the deficit of the Carolingian finds of the 9th century in the Trans-Danubian space. That is why we underline 
84) and being the conditional southern limit of settlement of the latter ones at the same time (Lampel 1915, 129; Dekan 1947, 201-202; Havlík 1956, 8; Ratkoš 1958, 8; Richter 1965, 130; Floria 1982, 84; Balcárková - Kalhous 2016, 118; Balcárková - Kalhous - Eichert 2017, 39; Mulík 2017, 21). ${ }^{19}$ That is why the spread of ecclesiastical jurisdiction of the Episcopacy of Passau to these areas had a strategic significance for both its clergy and the Carolingian court. In particular, it was necessary to Christianize the remnants of the surviving Avars between the Danube and the Raba rivers (Annales Tiliani 1966, 58; Lechner 1969, 41; Vlasto 2004, 36), as well as the numerous Slavic population in the Danube region (Krawarik 1970, 131-132; Krawarik 1971, 197; Krawarik 2002, 86; Krawarik 2008, 36-38; Čaplovič 1998, 103, 107; Balcárková - Kalhous - Eichert 2017, 38)20, and to subjugate them to the political authority of the Franks (Čaky 2016, 20), on what the Passau

the conventionality (sic!) of the Danube, as the Frankish-Slavic frontier and the boundary line of the future canonical confrontation between the Latin and the Cyril and Methodius church traditions at the same time.

19 Despite this, the Austrian historian Josef Lampel $(1915,129,134)$ considered the Thaya, a right tributary of the Morava, as the primary "Moravian border". The researcher admitted that only in the late Carolingian period, this frontier moved southward, to the Danube (Lampel 1915, 129). On the one hand, it seems to be quite obvious, considering the frankly unsuccessful attempts at the military-political confrontation of the last representatives of the Eastern Frankish line of the Carolingians: Arnulf (Arnolfus, 887 - 899), Louis IV the Child (Hludowicus, 900 - 911) as well as Conrad the Frankonian (Cuonradus, 911 - 918) [the first king not of the Carolingian dynasty - O. K.] with the Mojmirids and, in particular, with the Magyars (Bekker 2012, 940; Bodnariuk 2012, 831). According to J. Lampel $(1915,129)$, the mentioned "Moravian border" moved again northwards, to the "frontier river" Thaya under the strong impact of the Frankish and, especially, the new Saxon imperial policy. However, this river served as the ascending line for delineation of the Moravian lands, obviously, during the period of the Saxon dynasty of the Ludolfingers/Ottons (919 - 1024) and later (in the middle of the 11th century) (Havlík 2013, 355; Balcárková - Kalhous 2016, 119), when Moravia lost almost half of its possessions, particularly, the lands exactly between the Thaya and the Danube (Havlík 2013, 355). However, the Thaya River can't be used to outline the Frankish-Moravian frontier during the 9th century (sic!). We can absolutely agree with the assumption of A. Balcárková, D. Kalhous and S. Eichert that the boundaries of Great Moravia were not clearly established, and, consequently, the power of the Moravian rulers reached modern Lower Austria (Balcárková - Kalhous 2016, 18; Balcárková - Kalhous - Eichert 2017, 39) - in fact, to the Danube in the south (Lampel 1915, 129; Dekan 1947, 201-202; Floria 1982, 84; Dvornik 2005, 3). Thus, according to H. Krawarik $(2014,39)$, the Slavic cremation graves discovered north of the Danube are "the signe of Slavic immigration from Great Moravia".

20 Following the conclusions of the modern British medievalist Peter Heather (2016, 533-535), the process of large-scale Slavicization of European spaces east of the Elbe to the Volga River lasted during the 6th - 10th centuries, which is confirmed archaeologically. Consequently, north of the Danube, in particular, in the Naarn River basin, as well as in the south - in the the Enns River valley (a right tributary of the Danube) the numerous Slavic settlements also coexisted along with the Bavarian population (Krawarik 1971, 197; Krawarik 2002, 86; Krawarik 2008, 36, 92-93; Krawarik 2014, 89; Holub 2016, 116). It is evidenced by several Slavic necropolises of the 9th century on the northern bank of the Danube (in particular, 20 burials near Linz), numerous graves and settlements of the 7th - 9th centuries in the Eastern Danube region (Krawarik 2008, 36-38; Krawarik 2014, 81), a range of Slavic dwellings and the remains of the later Slavic settlement in Dietachdorf (in the present-day municipality of Dietach, the district of Steyr, Upper Austria) on the right bank of the Enns (Krawarik 2002, 86), as well as the early medieval Slavic artisan district discovered near the modern-day municipality of Mitterkirchen (the district of Perg, Upper Austria) and dated back to the early 9th century (Krawarik 2008, 37; Krawarik 2014, 39, 60). The last one may serve as archaeological evidence of the mentioned "Slavic immigration" from the territory of Moravia (Krawarik 2014, 39). Therefore, the spread of the ecclesiastical jurisdiction of the Episcopate of Passau and the Archbishopric of Salzburg and the administrative delimitation of their missionary spheres of influence in the outlined region was a completely legitimate measure of the Carolingians' church policy. 
clergy directed its main missionary efforts. Therefore, in the words of H. Krawarik $(2014,90)$, the missionary centers of Naarn, Ried, Saxen and Linz contributed to the [ecclesiastical - O. K.] "integration of the Slavs" in the outlined region.

One of the tasks of great priority for emperor Louis the Pious and, especially, for his son, the King of Bavaria Louis II the German, was to expand their influence even to the "heart" of the Moravian Prince Mojmir's state (Moimarus dux Maravorum, 795 - 846) - to the valley of the Morava River, which "was most easily accessible from the direction of Passau", according to the British historian Alexis Peter Vlasto $(1970,22 ; 2004,39)$. It was illustrated by the outlined missionary vector and the line of monastic centers of the aforementioned diocese along the Danube. However, in the late 820s the Diocese of Passau, de iure, according to the Czech historian Václav Medek $(1971,9)$ was only a neighbor of the principalities of Moravia and Nitrava, later united into the single Great Moravian state. After the administrative demarcation of territories of the dioceses of Salzburg and Passau in 796 and its confirmation in 829, in addition to Upper Pannonia and the lands north of the Danube, Moravia and Nitrava also passed into the sphere of influence of the Passau episcopate (CDEM I 1836, 18; MMFH III 1969, 120; Třeštík 2009, 161-162; Steinhübel 2016, 88, 125). But officially, Moravia wasn't subjected to the Episcopacy of Passau by any imperial document (in contradistinction to the imperial sanction concerning the transition of Lower Pannonia to the church jurisdiction of Salzburg) (Richter 1965, 130), despite the fact that the missionary activity of its clergy was evidential there. ${ }^{21}$ Neither Louis the Pious, neither his son Louis the German could sanction such subordination of the Moravians to the ecclesiastical jurisdiction of Passau, since their lands were independent of the empire (Třšstík 2009, 162).

In order to achieve the set goal, the Carolingians needed to provide Passau missionaries with the direct and permanent access to the core of Mojmir's state, where the Bishop of Passau Reginhar had previously baptized the Moravian elite (Chronicon monasterii 1721, 212; CDEM I 1836, 11; Vlasto 2004, 41; Wood 2001, 173-174), and about 831 performed a mass baptism of "all the Moravians" (“baptizat omnes Moravos”) (Bernardus 1880, 655; Notae 1880, 623; Lysý 2015, 91; Wood 2001, 174; Steinhübel, 2016, 125). ${ }^{22}$ That is why, in our opinion, King Louis II deliberately expanded the repeatedly mentioned missionary route of the clergy from the Diocese of St. Stephen further eastward, having extended its ecclesiastical jurisdiction to the new "possessions [...] that

${ }^{21}$ The early presence of missionaries from Passau in the Moravian possessions is testified, for example, by the discovery of necklace with a lead cross of Passau origin from the burial in Dolní Věstonice (Southern Moravia, the Czech Republic) (Sommer - Třeštík - Žemlička, Josef 2013, 225), as well as numerous pectoral crosses of Passau origin, discovered in the territory of Moravia (Kouril 2014, 109).

22 It should be emphasized that the Moravian elite headed by Prince Mojmir was baptized by Bishop Reginhar much earlier - between 818 and 825 (Chronicon monasterii 1721, 212; CDEM I 1836, 11; Vlasto 2004, 41; Wood 2001, 173-174). By this moment, the Moravians, a population of the Morava valley (an upper northern tributary of the Danube), which subsequently formed its own state called Great Moravia, hadn't been influenced by systematic Christianization, because the interests of the Carolingians didn't cover the territories located north of the Danube at that time (Hudeček 1936, 15; Poulík 1985, 11; Vlasto 2004, 37-38), mainly because of the Avar threat. In accordance with the statement of A. P. Vlasto (Vlasto 1970, 21; Vlasto 2004, 37-38), the local inhabitants hadn't had considerable contacts with the Christian world approximately until the beginning of the 9th century, because the style of many burials of the 7th - 8th centuries and the burial equipment excavated within them (for example, in Devínska Nová Ves, Eastern Slovakia) is Avarian. The Russian archaeologist-slavist Valentin Sedov $(1995,128)$ followed a similar point of view. Exactly on the verge of the 8th - 9th centuries the traditional Slavic pagan rite of cremation was replaced by the also pagan rite of inhumation (Floria 1988, 123; Ivanič 2011, 63; König 2017, 13-14). Such a crisis of traditional beliefs, according to the assumption of Boris Floria $(1988,123)$, could make the ruling elite of the local Slavic [and not only Slavic - O. K.] community "more susceptible to the preaching of Christian missionaries". 
are in the province of the Avars, in a place called Litaha, above the source named Sconibrunno" (MMFH III 1969, 32) ${ }^{23}$, i. e., the lands around the Leitha River (March 4, 833) (MMFH III 1969, 32-33; Erkens 1986, 92-93; Szőke 2009, 400); as well as the possessions "in a place called Kirichbach, that is, one constructed church with the land [...] up to the place called (Tumulus) and thence around up to the above-mentioned Kirichbac [...] and from there up to Cumenberg" (MMFH III 1969, 34$35)^{24}$, including Zeizzinmurus/Zeizzimurus (February 16, 836), mentioned in the extended version of the diploma of Louis I of June 28, 823 (CDEM I 1836, 13; MMFH III 1969, 118; Erkens 1986, 92-93; Weinzierl 2018, 22).

Similar territorial outline of the described donations is found in the late falsification (the last quarter of the 10th century) of the aforementioned diploma of Louis the Pious: "Litaha nearby the source called Sconibruno [...], and Zeizzimurus with such limit that our father Charles had established, that is, from that fortress in the eastern edge up to the hanging rock on the edge of the Mount Comageni, and up to the Chunihohesstetin in the south. Besides, up to the hills between Tullanam and the fortress itself in the west, and beyond the Danube to Trobinse, and thence up to Mochinleo, and as far as Zinbure and Treisma [...]" (CDEM I 1836, 13; MMFH III 1969, 118). ${ }^{25}$

23 "[...] res proprietatis [...], que sunt in provintia Auarorum in loco qui dicitur Litaha super fontem qui vocatur Sconibrunno [...]" (MMFH III 1969, 32). Sconibrunno -the modern-day Lower Austrian community of Schönabrunn (the district of Bruck an der Leitha), situated above the Leitha River (see the remark: MMFH III 1969, 32), in which territory one of the sleeves of the mentioned reiver flows. Most apparently, it is the same "fons Sconibrunno" from the diploma of Louis the German. However, in this case it is also about other lands around the Leitha, in particular, between the present-day communities of Götzendorf (the district of Bruck an der Leitha, Lower Austria) and Gattendorf (the district of Neusiedl am See, the state of Burgenland) (MMFH III 1969, 32). It's worth emphasizing that the Austrian historian Richard Müller $(1915,124)$ mistakenly denied the identification of Sconibrunno with modern-day Schönabrunn.

24 "[...] in loco qui dicitur Kirichbach, id est ecclesiam unam constructam cum territorio [...] usque ad locum qui dicitur (Tumulus) et inde per circuitum usque ad praedictum Kirichbach [...] et inde usque sursum Cumenberg" (MMFH III 1969, 34-35).

Kirichbach - the modern-day village of Kirchbach (the district of Tulln, Lower Austria) within the Vienna Woods (Reutter 1912, 34).

Tumulus -the present-day village of Tulbinger Kogel in the Lower Austrian community of Tulbing (the district of Tulln) (see the remark: MMFH III 1969, 34).

Cumenberg - one of the early medieval Latin nominations of the mountainous area of the Vienna Woods (the mountain range in the Eastern Alps), not far from Vienna, within Lower Austria, among the names "mons Comagenus", "Chumberg", "Cumeoberg", "Chumeoberg" (Koller 1963, 238-241; Haberl 1976, 155-156).

25 In Bishop Pilgrim's rigged text of the diploma-confirmation from 823 we find the following description: "[...] Litaha iuxta fontem, qui vocatur Sconibruno [...], et Zeizzimurus cum tali marcha, ut genitor noster Karolus decreuit, hoc est ab illo castello in orientali plaga adusque pendentem lapidem in ora montis Comageni, et in australi vsque ad Chunihohesstetin. In occidentali autem vsque ad aceruos sitos inter Tullanam et ipsum castellum et ultra Danubium ad Trobinse, et exinde ad Mochinleo et usque ad Zinbure et Treisma [...]" (CDEM I 1836, 13; MMFH III 1969, 118).

Chunihohesstetin - the modern-day community of Königstetten (the district of Tulln, Lower Austria) on the western slope of the Vienna Woods (see the remark: MMFH III 1969, 95; Lechner 1938, 38; Haberl 1976, 156).

Tullana - the present-day city of Tulln in Lower Austria (Müller 1915, 125; Haberl 1976, 156).

Trobinse - the modern-day community of Trübensee (the district of Tulln) in Lower Austria (Reutter 1912, 45; Müller 1915, 125; Lechner 1938, 32, 38).

Mochinleo - perhaps the present-day Lower Austrian community of Grossmugl (the district of Korneuburg) (Šembera 1858, 31; Reutter 1912, 45). However, the Austrian historian Karl Lechner (1938, $32)$, as well as R. Müller $(1915,125)$ before, identified this oikonim not with Grossmugl, but with the large 
On the one hand, this passage once again demonstrates the nature of the extended version of falsification of the diploma from 823, because the previously cited documents of King Louis II from March 4, 833 and from February 16, $836 \mathrm{p}$. formed a basis of the creation of the falsification (Müller, 1915, 124-125), which is evidenced by the resemblance of geographical descriptions of some newly-owned possessions of the Bishopric of Passau (Litaha, Sconibruno, Cumenberg/mons Comagenus). Another part of the territories (Chunihohesstetin, Tullana, Trobinse, Mochinleo, Zinbure) was granted to the diocese not in 823 , but only at the end of the 10th century (MMFH III 1969, 94; Lechner 1938, 38) ${ }^{26}$ On the other hand, this description serves as the evidence of a constant extending of the ecclesiastical jurisdiction of the Diocese of Passau to the east and north, illustrating the dynamics of the north-eastern border of the area of the St. Stephen eparchy even during the second half of the 10th century. ${ }^{27}$ Thus, Karl Lechner $(1938,32)$ considered that the above-drawn line of the Passau estates, in particular, the section of Wagram - Trübensee Mohho north of the Danube, was the Moravian-Bavarian frontier until the turn of the 10th - 11th centuries. Author's conviction about the late demarcation line of the Bavarian and the Moravian lands is, in our opinion, completely justified, taking into account that the Bishopric of Passau obtained the mentioned possessions exactly from the hands of the Bavarian Duke Henry II in 985 - 991 (MMFH III 1969, 94) just within the contact zone of the Bavarians and the Moravians (Krawarik 2014, 39; Balcárková - Kalhous - Eichert 2017, 38-39, 62), wherefrom the ecclesiastical jurisdiction of the Diocese of Passau spread further eastward. ${ }^{28}$

If we consider the royal land donations to the local Bavarian church dioceses as one of the signs of colonization and missionary development of a new space, then exactly these tasks were facing the Bishopric of Passau (Boshof 1995, 58). Undoubtedly, according to the conviction of the German historian Egon Boshof $(1995,58)$, this fact is confirmed by the benefaction of Emperor Louis from 823, particularly, by the land grants of Louis II the German to the Passau episcopate "in provintia Auarorum" from 833 [as well as by the donations from 836 - O. K.] and, in general, by the possessions between the Raba River and the Vienna Woods.

mound Mohho, located between the villages of Ober- and Unterzögersdorf (the district of Korneuburg, Lower Austria), which is quite possible, as in geographical aspect this barrow completely fit into the outline of the Passau land donations from the Bavarian King Louis.

It is very difficult to identify the toponym Zinbure in the diploma-falsification. For example, J. Lampel $(1915,151)$ associated it with the present-day Lower Austrian city of Eggenburg (the district of Horn). But in that case, Zinbure would be located too far north of the other toponyms mentioned in the falsification, in particular Treisma, which should be understood as present-day St. Pölten (Klebel 1955, 321; Erkens 1986, 87; Plesser 1998). It violates the logic of delineations of the Passau possessions "ultra Danubium ad Trobinse, et exinde ad Mochinleo et usque ad Zinbure et Treisma". It is also possible that the clerk of the late 10th century under the name Treisma could fix the territory of the present-day city of Traismauer (the district of St. Pölten, Lower Austria). So, we consider that Zinbure - is a settlement near the village of Wargam (the district of Tulln) in Lower Austria (see the remark: MMFH III 1969, 95). Perhaps, it is even one of the archaic names of the modern-day Lower Austrian city of Herzogenburg (the district of St. Pölten) on the Traisen River, between Traismauer and St. Pölten.

26 In fact, exactly that boundary of the Passau possessions, supplemented by a number of another toponyms, was recorded in the original diploma of the Bavarian Duke Henry II the Wrangler from 985 - 991 concerning the granting of lands in the Eastern March to the Passau episcopate (MMFH III 1969, 94).

27 The purpose of creating the falsification of the diploma from 823 testifies a need to confirm and expand the territorial rights of the Passau churchmen during the specified period (Erkens 1986, 93).

28 According to the German historian Eduard Mühle $(1996,222)$, exactly the falsifications of Bishop Pilgrim are the decisive testimony that the church ambitions of the Episcopate of Passau were directed not to "neighbour Moravia", but rather to "Moravia situated east of the Danube". 
Consequently, the sanctions of the Bavarian King reflected in the above-cited diplomas and the first-hand missionary activity of Reginhar gave the expected result to the ruling Carolingian court. The Bavarian clergy and politically organized Christianization received a direct access to the Moravian lands and provided Louis II with a stable form of indirect intervention in the policy of the Moravian Prince Mojmir and his successor Rostislav (Rasticius, 846 - 870) (Čáky 2016, 18). Henceforth, the ecclesiastical jurisdiction of the Diocese of St. Stephen, as well as the Carolingian political influence, gradually begun to cover the lands in the Morava basin and the boundary territories of Mojmir's state (Floria 1988, 124; Goldberg 2004, 75; Čáky 2016, 32; Botek 2018, 99), where the clergy from Passau carried out the evangelizing work and introduced the Church institutionalization, for a long time competing with the missionaries from Salzburg (Havlík 1963, 107; Botek 2018, 99). ${ }^{29}$

In general, the missionary potential of the Passau episcopate at the beginning of the 9th century was already so great, that the Frankish Emperor Louis I and his son, the Bavarian King Louis II began to donate new possessions in Marcha orientalis and Upper Pannonia to the Diocese of Passau. The analysis of the relevant diplomas from the chancellery of the Carolingians from 823, 833 and 836 , as well as the documents of later origin (the last quarter of the 10th century), demonstrated that the land estates granted to the St. Stephen Bishopric - Treisma, Wachowa, Pelagum, Nardinum, Reoda, Aspach, Wolffeswanch, Erlawa, Artagrum, Saxinum, Litaha, Zeizzinmurum, Kirichbach, Tumulus, Cumenberg - compiled not only a list of territorial acquisitions, but also formed a peculiar missionary route of the Passau clergy. The ecclesiastical connection between these lands, situated along the both banks of the Danube and its tributaries - the Naarn, Pielach, Erlauf and Leitha rivers, was established along the line of the most important monasteries, which existed there and were covered by the church jurisdiction of the Episcopacy of Passau. Such communication also coincided with the ancient Roman roads and later trade routes in the structure of the TransEuropean system of roads of the 9th century, which is proved archaeologically. In the 830s the outlined missionary route directly reached the possessions of the Moravian Prince Mojmir. There are weighty reasons to think that the Bavarian King Louis II intentionally extended the boundaries of the Bishopric of Passau eastwards, having attached to it the lands around the Leitha River and within the Vienna Woods in 833 - 836, in order to expand the ecclesiastical jurisdiction of the mentioned diocese, and, thus, his own royal influence further on the Great Moravian lands.

\section{REFERENCES}

Annales regni Frankorum. 1895. Annales regni Francorum inde ab A. 741. usque ad. A. 829. qui dicuntur Annales Laurissenses Maiores et Einhardi. In Pertz, Georg Heinrich - Kurze,

29 The Czech historian Lubimír Havlík $(1963,107)$ was convinced that the Mojmiroviches' possessions had never been a subject of the ecclesiastical jurisdiction of Passau, excepting the one-year period of the Frankish occupation during 870 - 871, and "the Christianization of Moravia wasn't the result of activities of only the Bavarian clergy". However, we don't agree with the authoritative researcher that the lands of the Mojmiroviches dynasty had never been covered by the jurisdiction of the Bavarian dioceses, in particular, of the Episcopate of Passau. Otherwise, how to explain the further long-lasting canonical and religiouspolitical confrontation between the Bavarian supreme clergy and the representatives of the Cyril and Methodius church tradition during the second half of the 9th century for the spheres of influence in Great Moravia? In addition, the fact of missionary activity of the Bavarian monasticism in this area is confirmed by numerous archaeological finds of the cult objects of the "Passau-Salzburg" origin (Kouřil 2014, 102). On the other hand, L. E. Havlík $(1963,107)$ was quite right, stating the presence of the Eastern Roman (Byzantine) and the Northern Italian ( Aquileian) missionary factors in the Mojmiroviches' possessions. 
Friderikus (eds.). Monumenta Germaniae Historica. Scriptores Rerum Germanicarum. Honnover.

Annales Tiliani. 1966. Annales Tiliani. In Bartoňková, Dagmar et al. (eds.). Magnae Moraviae Fontes Historici: Prameny k dějinám Velké Moravy, Tomus I : Annales et chronicae. Praguae Brunae, 58-59.

Balcárková, Adéla - Kalhous, David - Eichert, Stefan. 2017. Zur Entwicklung der Grenze im mährisch-österreichischen Grenzgebiet während des 11. - 12. Jahrhunderts und zur Rolle der Befestigung von Nikolausburg/Mikulov. In Beiträge zur Mittelalterarchäologie in Österreich 32, 37-72.

Balcárková, Adéla - Kalhous, David. 2016. Vývoj moravsko-rakouské hranice v raném středověku Mikulov - vstupní brána na území Moravy. In Památky archeologické 107, 117- 180.

Bekker, Karl. 2012. Древняя история [Ancient history]. Moscow.

Bernardus. 1880. Bernardi Cremifanensis historiae. In Pertz, Georg H. (ed.). Monumenta Germaniae Historica, Tomus XXV : Scriptorum. Hannover, 651-678.

Bodnariuk, Bogdan Mykhailovych. 2012. Харизма пустелі. Витоки, становлення, духовноаскетична і місіонерська практика християнського чернецтва III-XI ст. [Charisma of desert. Origins, formation, spiritual-ascetic and missionary practice of Christian monasticism of the $3^{\text {th }}-11^{\text {th }}$ centuries]. Chernivtsi.

Boshof, Egon. 1995. Das Schreiben der bayerischen Bischöfe an einen Papst Johannes - eine Fälschung Pilgrims? In Dahlhaus, Joachim - Kohnle, Armin (eds.). Papstgeschichte und Landesgeschichte. Festschrift für Hermann Jakobs zum 65. Geburstag. Köln - Weimar - Wien, 37-67.

Botek, Andrej. 2014. Vel'komoravské kostoly na Slovensku a odraz ich tradície v neskoršom období. Bratislava.

Botek, Andrej. 2018. K otázke možnej kanonizácie našich panovníkov z najstarších dejín. In Historický zborník: vedecký časopis o slovenských národných dejinách 28/1, 91-116.

Bowlus, Charles R. 1995. Franks, Moravians and Magyars: The Struggle for the Middle Danube, 788 - 907. Philadelphia.

Čáky, Milan. 2016. Politický a štátotvorný význam vel'komoravskej a cyrilo-metodskej tradície. Brno.

Čaplovič, Dušan. 1998. Včasnostredoveké osídlenie Slovenska. Bratislava.

CDEM I. 1836. Boczek, Antonius (ed.). Codex diplomaticus et epistolaris Moraviae, Tomus I : 896 - 1199. Olomucium.

Chronicon monasterii. 1721. Chronicon monasterii Mellicensis, ab anno primo Aerae Christi ad annum ejusdem MDLXIV. In Pez, R. D. P. Hieronimus (ed.). Scriptores Rerum Austriacarum, Tomus I. Lipsia, 163-288.

Dekan, Ján. T. 1947. Príspevok k otázke politických hraníc Vel'kej Moravy In Varsik, Branislav (ed.). Historica Slovaca, Tomus 5, 198-211.

Dessl OCist, Reinhold J. 2002. Der Hl. Laurentius in Oberösterreich. Eine Beitrag zur Geschichte seiner Kirchenpatrozinien. In Jahrbuch des Oberösterreichischen Musealvereines 147, 169-180.

Dubski, Rainald. 2012. Grundherrschaft und Christianisierung als prägende Elemente des Grenzsaumes zu Ungarn und Mähren - Vom Ende der Frankenherrschaft bis zum Beginn des hohen Mittelalters. Dissertation angestrebter akademischer Grad PhD. Universität Wien. Wien.

Dvornik, Francis. 2005. Слов'яни в європейській історії та цивілізації [The Slavs in European History and Civilization]. Kyiv. 
An Attempt at Delineation of the Eastern Missionary Route of the Clergy of Passau on the Lands of the Post-Avar Danube Region During the First Half of the 9th Century

Erkens, Franz-Reiner. 1986. Ludwigs des Frommen Urkunde vom 28. Juni für Passau (MB'2778). In Deutsches Archiv für Erforschung des Mittelalters 42, 86-117.

Fedeles, Tamaš - Koszta László. 2011. Pécs (Fünfkirchen). Das Bistum und die Bischofsstadt im Mittelalter. In Fazekas, István et al. (eds.). Publikationen der Ungarischen Geschichtsforschung in Wien 2. Wien.

Floria, Boris Nikolaevich. 1982. О самосознании великоморавской народности [About the selfconsciousness of the Moravian people]. In Koroliuk, Vladimir Dorofeevich (ed.). Развитие этнического самосознания славянских народов в эпоху раннего средневековья [The development of ethnic identity of the Slavic peoples in the early Middle Ages]. Moscow, 82-96.

Floria, Boris Nikolaevich. 1988. Принятие христианства в Великой Моравии, Чехии и Польше [The adoption of Christianity in Great Moravia, Czech and Poland]. In Litavrin, Gennadiy Grigor'evich (ed.). Принятие христианства народами Центральной и Юго-Восточной Европы и крещение Руси [The adoption of Christianity by the peoples of Central and SouthEastern Europe and the baptism of Rus']. Moscow, 122-158.

Gassner, Verena - Pülz, Andreas. 2015. Der römische Limes in Österreich: Führer zu den archäologischen Denkmälern. Wien.

Genser, Kurt. 1982. Neues zu einigen Wirkungsstätten des heiligen Severin. In Mitteilungen der Gesellschaft für Salzburger Landeskunde 122, 61-70.

Geschichtliche Beilagen. 1890. Geschichtliche Beilagen zu den Consistorial-Currenden der Diöcese St. Pölten. Bd. 4. St. Pölten.

Goldberg, Eric J. 2004. Ludwig der Deutsche und Mähren. Eine Studie zu karolingischen Grenzkriegen im Osten. In Hartmann, Wilfried (ed.). Ludwig der Deutsche und seine Zeit. Darmstadt, 67-94.

Good, Leanne Marie. 2012. Land and Landscape: The Transformation from Agilolfing to Carolingian Bavaria, 700 - 900. PhD Thesis. University of California. Los Angeles.

Haberl, Johanna. 1976. Favianis, Vindobona und Wien: Eine archäologisch-historische Illustration zur Vita S. Severini des Eugippius. Leiden.

Havlík, Lubomír E. 1956. Znojemské hradiště sv. Hypolita. Příspěvek k nejstarším dějinám církevní organisace na Moravě. Brno.

Havlík, Lubomír E. 1963. Byzantská mise a Velká Morava. In Sborník Matice moravské 82, 105-131.

Havlík, Lubomír E. 1998. Dějiny Královského města Znojma a znojemského kraje od nejstarších dob do sedmdesátých let 19. století. Brno.

Havlík, Lubomír E. 2013. Kronika o Velké Moravě. Brno.

Heather, Peter. 2016. Великие завоевания варваров. Падение Рима и рождение Европы [Empires and Barbarians. The Fall of Rome and the Birth of Europe]. Moscow.

Holub, Zbyněk. 2014. Jazykové doklady prehistorické podunajské migrace slovanského etnika na český jih. Opava.

Hudeček, Jakub. 1936. Vývoj církevního zřízení na Moravě v IX. a X. století. In Sborník velehradský 7, 15-43.

Ivanič, Peter. 2007. Predcyrilometodské misie na území dnešnej Moravy a Slovenska z pohladu českej a slovenskej historiografie. In Michalov, Jozef et al. (eds.). Duchovné, intelektuálne a politické pozadie Cyrilometodskej misie pred jej príchodom na Vel'kú Moravu. Nitra, 46-59.

Ivanič, Peter. 2011. Západní Slovania v ranom stredoveku: história, kultúra, hospodárstvo, náboženstvo. Nitra.

Klebel, Ernst. 1954. Eichstätt und Herrieden im Osten. In Jahrbuch für fränkische Landesforschung 14, 87-96.

Klebel, Ernst. 1955. Zur Kritik der Urkunde Ludwigs des Frommen für Passau vom 28. 6. 823. In Archivalische Zeitschrift 50/51, 319-327. 
Klíma, Bohuslav F. 2000. Slovanské výšinné hradiště sv. Hypolita ve Znojmě - velkomoravské mocenské centrum Jz. Moravy. In Klíma, Bohuslav F. (ed.). Staroslovanská Morava. Sylaby přednášek ze semináře pro účitele ZŠ a SŠ. Drobné studijni texty - svazek 2. Brno, 55-70.

Klíma, Bohuslav F. 2010. Using the results of the Archaeological Excavations of the Department in Znojmo-Hradiště to the knowledge of Early Christianity in Moravia. In Sborník prací Pedagogické fakulty Masarykovy univerzity v Brně, řada společenských věd 24/2, 3-12.

Klíma, Bohuslav. 2001a. Objev prvního velkomoravského kostela na hradišti sv. Hypolita ve Znojmé. In Sborník prací Pedagogické fakulty Masarykovy univerzity v Brně, řada společenských věd $18,3-24$.

Klíma, Bohuslav. 2001b. Od počátků archeologických výzkumů MU na Velkomoravském výšinném hradišti sv. Hypolita ve Znojmě k posledním objevům. In Podborský, Vladimír (ed.). 50 let archeologických výzkumů Masarykovy univerzity na Znojemsku. Brno, 37-56.

Knappek, Ludevit. 1935. Cirkev a stat v boji o rozšírenie krestanstva v IX. storočí. Príspevok k charakteristike christianizácie kniežatstva Pribinovho a ríše Velkomoravskej. In Stanislav, Ján (ed.). Ríša Vel'komoravska: sborník vedeckých prác. Praha, 231-253.

Koller, Heinrich. 1963. Der "mons Comagenus". In Mitteilungen des Instituts für Österreichische Geschichtsforschung 71, 237-245.

Konečný, Lubomír. 1975 - 1976. Nejstarší politicko-církevní ústředí Moravy. In Sborník prací Filozofickej fakulty Brněnskej univerzity 24/25, 9-22.

König, Tomáš. 2017. The Great Moravian territory of Nitra. Cultural manifestations, territorial scope and the ethnic and social-political identity of its population. In Muzeológia a kultúrne dedičstvo 5/2, 9-28.

Kouřil, Pavel. 2014. Archeological evidence of Christianity in relics of material culture of the 9th and 10th centuries in Moravia with focus on crosses. In Kouril, Pavel et al. (eds.). The Cyril and Methodius Mission and Europe. 1150 Years Since the Arrival of the Thessaloniki Brothers in Great Moravia. Brno, 102-113.

Kožiak, Rastislav. 2006. Christianizácia Avarov a Slovanov na strednom Dunaji: Príbeh svätcov-misionárov, svätá vojna alebo kultúrny šok. In Kožiak, Rastislav - Nemeš, Jaroslav (eds.). Studia Christiana, Vol. I. Bratislava, 121-147.

Krawarik, Hans. 1970. 850 Jahre Windischgarsten. In Jahrbuch des Oberösterreichischen 115, 129-154.

Krawarik, Hans. 1971. Zur Siedlungsgeschichte des Pyhrnpassraumes. In Jahrbuch des Oberösterreichischen Musealvereines 116, 195-212.

Krawarik, Hans. 2002. Frühmittelalterliche Erschliessung im Unteren Traungau. In Jahrbuch des Oberösterreichischen Musealvereines 147/1, 75-125.

Krawarik, Hans. 2008. Das Machland und seine Herren. In Mitteilungen des Oberösterreichischen Landesarchivs 21, 31-106.

Krawarik, Hans. 2014. Siedlungsprozesse des Frühmittelalters im Mühlviertel. In Jahrbuch der Gesellschaft für Landeskunde und Denkmalpflege Oberösterreich 159, 37-112.

Kučera, Matúš. 1985. Vel'ká Morava: spoločnost', kultúra, tradícia. Bratislava.

Lampel, Josef. 1915. Der mährische Anteil am Gemärke des Landbuches. In Jahrbuch für Landeskunde von Niederösterreich 13/14, 28-156.

Lechner, Karl. 1938. Die geschichtliche Landschaft zwischen Donau und Wagram. In Jahrbuch für Landeskunde von Niederösterreich. Serie: Neue Folge 27, 30-70.

Lechner, Karl. 1969. Die salzburgisch-passauische Diözesanregulierung in der Buckligen Welt im Rahmen der Landschaftsgeschichte des 9. Jahrhunderts. In Mitteilungen der Gesellschaft für Salzburger Landeskunde 109, 41-64. 
An Attempt at Delineation of the Eastern Missionary Route of the Clergy of Passau on the Lands of the Post-Avar Danube Region During the First Half of the 9th Century

Leont'ev, Andrey Yevgenevich - Nosov, Evgeniy Nikolaevich. 2012. Восточноевропейские пути сообщения и торгвые связи в конце VIII - X в. [Eastern European communication routes and trade relations at the end of the $8^{\text {th }}-10^{\text {th }}$ centuries]. In Makarov, Nikolay Andreevich (ed.). Русь в IX - X веках. Археологическая панорама [Rus' in the $9^{\text {th }}-10^{\text {th }}$ centuries. Archaeological panorama]. Moscow - Vologda, 383-401.

Lysý, Miroslav. 2015. "Omnes Marahoni insimul mandaverunt": мораване как этнос и политическая единица. [“Omnes Marahoni insimul mandaverunt": the Moravians as an ethnos and political entity]. In Studia Slavica et Balcanica Petropolitana 2, 82-98.

Marsina, Richard. 1992. Kristianizácia Madarov a Uhorska medzi východom a západom. In Historický časopis 40/4, 409-421.

Marsina, Richard. 2012a. Benediktínske opátstvo (kláštor) sv. Hypolita na Zobore (Čas vzniku, patronát, diplomatická činnost'). In Studia Historica Tyrnaviensia 14/15, 19-31.

Marsina, Richard. 2012b. Metodov boj. Bratislava.

Maurer, Hermann. 1985. Waldviertel 1985. Einführung in die Jahrestagung 1985 der Gesellschaft für vor- und Frühgeschichte in Pulkau. In Mannus-Bibliothek 23. Bonn.

Medek, Václav. 1971. Osudy moravské církve do konce 14. věku. I. Díl : Dějin olomoucké arcidiecéze. Praha.

MMFH III. 1969. Bartoňková, Dagmar et al. (eds.). Magnae Moraviae Fontes Historici: Prameny k dějinám Velké Moravy, Tomus III : Diplomata. Epistolae. Textus historici varii. Brno.

Mühle, Eduard. 1996. Altmähren oder Moravia? Neue Beiträge zur geographischen Lage einer frühmittelalterlichen Herrschaftsbildung im östlichen Europa. In Zeitschrift für Ostmitteleuropa-Forschung 46/2, 205-223.

Mulik Peter. 2017. Pojem slovenského územia z historicko-geografického a historicko-lingvistického aspektu v najstaršom období. In Letz, Róbert et al. (eds.). Slovenské územie. Martin, 15-32.

Müller, Richard. 1915. Frauen Helchen Burg. In Jahrbuch für Landeskunde von Niederösterreich 13/14, 112-127.

Notae. 1880. Notae de episcopis Pataviensis. In Pertz, Georg H. (ed.). Monumenta Germaniae Historica, Tomus XXV : Scriptorum. Hannover, 623-627.

Nótári, Tomás. 2007. Conversio Bagoariorum et Carantanorum - document of an early Medieval show trial. In Publicationes Universitatis Miskolcinensis. Sectio Juridica et Politica, 25/1, 95-119.

Parello, Daniel. 2015. Die mittelalterlichen Glasmalereien in Regensburg und der Oberpfalz (ohne Regensburger Dom). In Corpus Vitearum Medii Aevi 13/2. Berlin.

Plesser, Alois. 1998. Zur Kirchengeschichte des Viertels ob dem Wienerwald vor 1627. In Geschichtliche Beilagen zum St. Pöltner Diözesanblatt 16. St. Pölten.

Poulik, Josef. 1985. Great Moravia and the mission of Cyril and Methodius. Prague.

Ratkoš, Peter. 1958. Vel'komoravské obdobie v slovenských dejinách. In Historický časopis 6/1, 3-31.

Ratkoš, Peter. 1971. Kristianizácia Velkej Moravy pred misiou Cyrila a Metoda. In Historický časopis 19/1, 71-83.

Reutter, Hans. 1912. Ein fränkisches Grenz- und Siedlungssystem in den karolingischen Südostmarken. In Jahrbuch für Landeskunde von Niederösterreich 10, 1-108.

Richter, Václav. 1965. Die Anfänge der grossmährischen Architektur. In Macůrek, Josef (ed.). Magna Moravia: sborník k 1100. výročí příchodu byzantské mise na Moravu. Praha, 121-360. Rops, Daniel. 2014. Kościoł wczesnego średniowiecza. Warszawa.

Ruttkay, Alexander T. 2007. O počiatkoch krestanstva a najstarších sakrálnych architektúrach na území Slovenska. In Michalov, Jozef et al. (eds.). Poznávanie Kultúrneho dedičstva sv. Cyrila 
a Metoda. Monografia príspevkov z medzinárodnej vedeckej konferencii. Nitra, 3. júl 2007. Nitra, 40-53.

Ruttkay, Alexander T. 2016. O počiatkoch krestanstva na území Slovenska, význame cyrilo-metodskej misie a jej odozvách v 10.-11. storočí. In Konštantínove listy 9/2, 2-10.

Schwarcz, Andreas. 2016. Koexistenz im Untergang. Das Leben mit dem Barbaren am norischen Limes im 5. Jahrhundert. In Der Donaulimes in der Spätantike und im Frühmittelalter 22, 77-88.

Sedov, Valentin Vasilevich. 1995. Славяне в раннем Средневековье, T. 2 [The Slavs in the early Middle Ages, Vol. 2]. Moscow.

Šembera, Alois V. 1858. Dějiny řeči a literatury československé. Vídeň.

Sommer, Petr - Třeštík, Dušan - Žemlička, Josef. 2013. Čechy a Morava. In Berendová, Nora (ed.).

Christianizace a utváření křestanské monarchie. Skandinávie, střední Evropa a Rus v období 10. - 12. století. Praha, 219-261.

Štefanovičová, Tatiana. 1989. Osudy starých Slovanov. Martin.

Steinhübel, Ján. 1995. Vel'komoravské územie v severovýchodnom Zadunajsku. Bratislava.

Steinhübel, Ján. 2014. Krestanstvo medzi Velkou Moravou a Uhorskom : otázka kontinuity a discontinuity. In Historia Sclavorum Occidentis 1/6, 42-61.

Steinhübel, Ján. 2016. Nitrianske kniežatstvo. Počiatky stredovekého Slovenska. Bratislava.

Štih, Peter. 2010. The Middle Ages between the Eastern Alps and Northern Adriatic: Selected

Papers on Slovene Historiography and Medieval History. In East Central and Eastern Europe in the Middle Ages, 450 - 1450. Vol. 11. Leiden - Boston.

Szőke Béla. M. 2002. Christliche Denkmäler in Pannonien aus der Karolingzeit. In Zalai Múzeum 11, 247-266.

Szőke, Béla. M. 2009. Karolingische Kirchenorganisation in Pannonien. In Glaube, Kult und

Herrschaft. Phänomene des Religiösen im 1. Jahrtausend n. Chr. in Mittel- und Nordeuropa 12, 395-416.

Tisch, Peter, J. 2013. Überraschende Entdeckungen in der Pfarrkirche Wolfsbach. Neue Beobachtungen bei den Grabungsarbeiten. In VEMOG (ed.). Mosaik Steine. Spurensuche in der Mostviertler Geschichte. Linz, 86-103.

http://vemog.at/wp-content/uploads/2015/12/wolfsbach-archäologie-Pater-Jacobus-Tisch.pdf

Třštík, Dušan. 2009. Powstanie Welkich Moraw. Morawianie, Czesi I Europa Środkowa w latach 791 - 871. Warszawa.

Vlasto, Alexis P. 1970. The Entry of the Slavs into Christendom. An Introduction to the Medieval History of the Slavs. Cambridge.

Vlasto, Alexis P. 2004. Запровадження християнства у слов'ян. Вступ до середньовічної історії слов'янства [The Entry of the Slavs into Christendom. An Introduction to the Medieval History of the Slavs]. Kyiv.

Weber, Andreas O. 1999. Studien zum Weinbau der altbayerischen Klöster im Mittelalter: Altbayern - österreichischer Donauraum - Südtirol. Stuttgart.

Weinzierl, Herbert F. 2018. Nachanticke Siedlungsentwicklung am römischen limes in Österreich. Wien.

Winter, Otto F. 1998. St. Lorenzi in der Wachau (St. Lorenz, Marktgemeinde Rossatz-Arnsdorf). In Jahrbuch für Landeskunde von Niederösterreich 63/64, 429-447.

Wolfram, Herwig. 1972. Der heilige Rupert und die antikarolingische Adelsopposition. In Mitteilungen des Instituts für Österreichische Geschichtsforschung 80, 4-34.

Wolfram Herwig. 2011. Die ostmitteleuropäischen Reichsbildungen um die erste Jahrtausendwende und ihre gescheiterten Vorläufer. In Hlaváček, Ivan - Patschovsky, Alexander (eds.). Böhmen 
An Attempt at Delineation of the Eastern Missionary Route of the Clergy of Passau on the Lands of the Post-Avar Danube Region During the First Half of the 9th Century

und seine Nachbarn in der Přemyslidenzeit (In Vorträge und Forschungen 74). Ostfildern, 49-90.

Wood, Ian. 2001. The Missionary Life: Saints and the Evangelisation of Europe $400-1050$. Harlow - New York.

\section{Ostap Kardash}

Vasyl Stefanyk Precarpathian National University

Faculty of history, politology and international relations

Department of world history

Centrum Studiorum Mediaevalium

Shevchenko St., 57,

76018, Ivano-Frankivsk,

Ukraine

ostap.kardash@gmail.com 